\title{
Phosphorus transformations as a function of pedogenesis: A synthesis of soil phosphorus data using Hedley fractionation method
}

\author{
X. Yang and W. M. Post \\ Oak Ridge National Lab, Oak Ridge, TN 37831, USA \\ Received: 7 June 2011 - Published in Biogeosciences Discuss.: 28 June 2011 \\ Revised: 15 September 2011 - Accepted: 26 September 2011 - Published: 17 October 2011
}

\begin{abstract}
In spite of the importance of phosphorus (P) as a limiting nutrient in terrestrial ecosystems, our understanding of terrestrial $\mathrm{P}$ dynamics and our ability to model $\mathrm{P}$ cycling are hampered by the lack of consistent measurements of soil P. The Hedley fractionation method provides a comprehensive assessment of soil $\mathrm{P}$ and has been widely used in recent decades. Here we expand an earlier study that summarized Hedley P data from the literature to create a larger Hedley $P$ database and further investigate the relationships between distributions of different forms of $\mathrm{P}$ and the stages of soil development. Our expanded Hedley P database generally supports what the Walker and Syers (1976) conceptual model predicts: the gradual decrease and eventual depletion of primary mineral $\mathrm{P}$ (mainly apatite $\mathrm{P}$ ); the continual increase and eventual dominance of occluded P; and the overall decrease of total P during soil development. However the analysis disagrees with Walker and Syers (1976) in that we found labile inorganic $\mathrm{P}(\mathrm{Pi})$ and secondary mineral $\mathrm{Pi}$ (non-occluded $\mathrm{P}$ in Walker and Syers' model) to be a significant fraction of total $\mathrm{P}$ throughout all soil orders with different weathering stages. By analyzing the Hedley-labile $\mathrm{P}$ and vegetation $\mathrm{P}$ demand, we found that the amount of labile $\mathrm{P}$ is much greater than vegetation demand, even in highly weathered soils commonly considered P limited. We conclude that labile P measured by Hedley fractionation method should not be defined as plant available $\mathrm{P}$ since most of this labile $\mathrm{P}$ likely ends up as immobilized by microbes. Our analysis of the database also shows that carbon $(\mathrm{C})$ and nitrogen $(\mathrm{N})$ in soil organic matter are closely linked in all soil orders, but $\mathrm{P}$ is decoupled
\end{abstract}

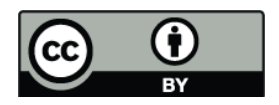

Correspondence to: X. Yang (yangx2@ornl.gov) from $\mathrm{C}$ and $\mathrm{N}$ in highly weathered soils with larger variations of nitrogen:organic $\mathrm{P}(\mathrm{N}: \mathrm{Po})$ ratio and higher mean values of $\mathrm{N}$ :Po ratio, compared to slightly and intermediately weathered soils.

\section{Introduction}

Phosphorus $(\mathrm{P})$ is an essential nutrient that often limits plant productivity, especially in tropical regions (Elser et al., 2007; Vitousek and Howarth, 1991; Wardle et al., 2004). Unlike nitrogen $(\mathrm{N})$, which is supplied by $\mathrm{N}$ fixers or directly from the atmosphere in fixed form, the primary source of $\mathrm{P}$ for terrestrial ecosystems is rock weathering. Therefore $\mathrm{P}$ has been considered the ultimate limiting soil nutrient in terrestrial ecosystems (Walker and Syers, 1976).

Although many methods have been devised to measure soil P, such as Olsen bi-carbonate method (Olsen, 1954), Bray-I (Bray and Kurtz, 1945), Mehlich-I (Nelson et al., 1953), these methods focus on the soil labile $P$ only and do not provide information on either other forms of $\mathrm{P}$ such as occluded P or total P. In recent years, the Hedley sequential fractionation method (Hedley and Stewart, 1982; Tiessen and Moir, 1993), which first removes labile inorganic $\mathrm{P}(\mathrm{Pi})$ and organic $\mathrm{P}(\mathrm{Po})$ and then the more stable $\mathrm{Pi}$ and Po using sequentially stronger extracting agents (first anion exchange resin, followed by $0.5 \mathrm{M} \mathrm{NaHCO}_{3}, 0.1 \mathrm{M} \mathrm{NaOH}$ and $1 \mathrm{M} \mathrm{HCl}$ ), has gained considerable attention as a useful tool to examine different forms of soil $\mathrm{P}$ and provides a comprehensive assessment of available P in soils (Johnson et al., 2003). Condron and Newman (2011) acknowledged the important role of Hedley fractionation method in the study of

Published by Copernicus Publications on behalf of the European Geosciences Union. 
$\mathrm{P}$ dynamics in soils and provided specific recommendations on Hedley fraction procedures in order to minimize limitations and advance the usefulness of this method. Since Cross and Schlesinger (1995) summarized literature on the Hedley fractionation $\mathrm{P}$ data in natural terrestrial ecosystems, there were additional studies (see Supplement) on P content in natural ecosystems using the Hedley fractionation method, especially for soil orders not well represented or absent in Cross and Schlesinger (1995), such as Andisols, Ultisols, Oxisols, Spodosols and Histosols. For agroecosystems Negassa and Leinweber (2009) provided a review on how Hedley fractionation $P$ data reflected impacts of land use and management on soil $\mathrm{P}$, by summarizing $\mathrm{P}$ data obtained by the Hedley fraction method in contrasting land-use and management systems.

Walker and Syers' conceptual model (1976) suggested that a relationship exists between $\mathrm{P}$ content and forms in soils and stage of soil development. All soil P is in the primary mineral form (mainly as apatite in most soils) at the beginning of soil development. With time, primary $\mathrm{P}$ minerals weather, giving rise to phosphorus in various other forms (organic P, non-occluded $\mathrm{P}$, occluded $\mathrm{P}$ ) and to a decline of total $\mathrm{P}$ due to leaching. The soluble $\mathrm{P}$ released from primary minerals can be taken up by biota, entering the organic $\mathrm{P}$ reservoir, or sorbed onto the surface of secondary minerals in soils to become "non-occluded P". The non-occluded $\mathrm{P}$ is slowly but continually converted to occluded $\mathrm{P}$ with time, as $\mathrm{P}$ is physically encapsulated or surrounded by secondary minerals (such as $\mathrm{Fe}$ and $\mathrm{Al}$ oxides). Therefore at the late stage of soil development, soil $\mathrm{P}$ is dominated by organic P and occluded P. The Walker and Syer's conceptual model has been tested using chronosequence studies and Hedley P data from natural ecosystems (Crews et al., 1995; Cross and Schlesinger, 1995). However there was very limited number of measurement for several soil orders in Cross and Schlesinger (1995). In particular, there was only one measurement for Oxisols.

Hedley $\mathrm{P}$ data also allow us to quantify $\mathrm{P}$ available for plants. Quantifying available $P$ in soils, which has been traditionally defined as $\mathrm{P}$ in soil solution plus $\mathrm{P}$ that enters soil solution during a growing season, remains elusive. Available $\mathrm{P}$ is a concept rather than a measurable quantity, because $\mathrm{P}$ may enter the solution through desorption or dissolution of inorganic $\mathrm{P}$ associated with soil minerals, or by mineralization of organic P (Tiessen and Moir, 1993). It has been defined as the sum of resin Pi, bicarbonate Pi and Po using Hedley fractionation method (Cross and Schlesinger, 1995; Johnson et al., 2003; Tiessen and Moir, 1993). In particular, Johnson et al. (2003) evaluated available P in forest soils using Hedley P data from Cross and Schlesinger (1995) and they found that pools of labile P determined by Hedley fractionation method are greater than the annual forest $P$ requirement even in tropical soils that are considered P limited. Their findings underscore the need to further investigate the implications of available $\mathrm{P}$ defined using the Hedley fractionation method to P limitation in terrestrial ecosystems.
Recently, a growing interest in ecological stoichiometry (Elser et al., 2000; Sterner and Elser, 2002) has led to a broader use of $\mathrm{C}: \mathrm{N}: \mathrm{P}$ in plants to infer nutrient limitation in terrestrial ecosystems (Hedin, 2004; McGroddy et al., 2004; Reich and Oleksyn, 2004). For example, McGroddy et al. (2004) used data from the literature to examine the stoichiometry of C, N, P in forest foliage and litter on both global and biome scales. Their study showed that $\mathrm{C}: \mathrm{P}$ and $\mathrm{N}: \mathrm{P}$ ratios in tropical forests are substantially higher compared to temperate forests and that the differences are more strongly expressed in litter than in foliage, suggesting a higher P resorption rate in tropics. Previous studies have also investigated the stoichiometry of $\mathrm{C}: \mathrm{N}: \mathrm{P}$ in microbial biomass and soils (Cleveland and Liptzin, 2007; Tian et al., 2010). However, those studies used measurements of total soil $\mathrm{P}$, which includes not only organic $\mathrm{P}$, but also $\mathrm{P}$ in primary mineral particles, occluded form, as well as $\mathrm{P}$ adsorbed on surfaces of soil minerals. Comparing $\mathrm{C}, \mathrm{N}, \mathrm{P}$ ratios using organic $\mathrm{P}$, rather than total $\mathrm{P}$, could be a more relevant analysis since much of total $\mathrm{P}$ occurring in primary mineral form, secondary mineral form or occluded form is of limited biological availability while the turnover of organic $\mathrm{P}$ comprises a rapid cycle of $\mathrm{P}$ in ecosystems, approximately an annual cycle, which likely provide most of $\mathrm{P}$ taken up by plants. Since nearly all Hedley fractionation method studies also measured soil organic $\mathrm{C}$ and $\mathrm{N}$, we were able to investigate the $\mathrm{C}: \mathrm{N}$ :Po stoichimetry in soils.

The objectives of this study were fourfold: (1) expand Cross and Schlesinger (1995) by adding recent data (after 1995) on $P$ fractions measured using Hedley fractionation method to create a larger Hedley P database; (2) further evaluate the relationships between the distributions of different $P$ forms and the stages of soil development and reexamine the Walker and Syers' conceptual model; (3) further evaluate available $\mathrm{P}$ using the expanded Hedley $\mathrm{P}$ database. In particular, we are interested in how soil labile $\mathrm{P}$, defined using the Hedley fractionation method, varies with pedogenesis and whether it can be used as a proxy for plant available P; and (4) examine C:N:Po patterns in soils with different weathering stages in order to further understand the relationship between ecosystem processes and transformations of soil organic $\mathrm{P}$.

\section{Methods}

\subsection{Data sources and data structure}

We compiled a database of soil P fractions by surveying the peer-reviewed literature that cited the Hedley fractionation method (Hedley and Stewart, 1982). We restricted our survey to studies for natural, unfertilized, and uncultivated soils. In addition, since Cross and Schlesinger (1995) provided a comprehensive survey on Hedley $\mathrm{P}$ data, we restricted our survey to studies after 1995 . We found 90 additional soil 
Table 1. Database fields and descriptions.

\begin{tabular}{|c|c|c|c|}
\hline & Field Name & $\begin{array}{l}\text { Extraction Agent } \\
\text { in Hedley Fractionation method }\end{array}$ & Description \\
\hline 1 & Soil Order & & USDA major soil order \\
\hline 2 & Resin Pi & Resin strip in water & Labile Pi (Unit: $\mathrm{mg} \mathrm{P} \mathrm{kg}^{-1}$ ) \\
\hline 3 & Bicarbonate Pi & $0.5 \mathrm{M} \mathrm{NaHCO}_{3}$ & Labile Pi(Unit: $\mathrm{mg} \mathrm{P} \mathrm{kg}^{-1}$ ) \\
\hline 4 & Hydroxide Pi & $0.1 \mathrm{MNaOH}$ & $\begin{array}{l}\text { Secondary mineral Pi: adsorped to surfaces of } \mathrm{Al} \text { and } \\
\text { Fe oxides(Unit: } \mathrm{mg} \mathrm{P} \mathrm{kg}^{-1} \text { ) }\end{array}$ \\
\hline 5 & Sonic Pi & $0.1 \mathrm{M} \mathrm{NaOH}$ and sonicate & $\begin{array}{l}\text { Secondary mineral Pi: adsorped within surfaces of } \mathrm{Al} \text { and } \\
\text { Fe oxides (Unit: } \mathrm{mg} \mathrm{P} \mathrm{kg}^{-1} \text { ) }\end{array}$ \\
\hline 6 & Apatite $\mathrm{P}$ & $1 \mathrm{MHCl}$ & Apatite $\mathrm{P}$ (Unit: $\mathrm{mg} \mathrm{P} \mathrm{kg}^{-1}$ ) \\
\hline 7 & Residue $\mathrm{P}$ & $\mathrm{H}_{2} \mathrm{SO}_{4}$ and $\mathrm{H}_{2} \mathrm{O}_{2}$ & Occluded P (Unit: $\mathrm{mg} \mathrm{P} \mathrm{kg}^{-1}$ ) \\
\hline 8 & Bicarbonate Po & $0.5 \mathrm{M} \mathrm{NaHCO}_{3}$ & Labile Po, easily mineralized (Unit: $\mathrm{mg} \mathrm{P} \mathrm{kg}^{-1}$ ) \\
\hline 9 & Hydroxide Po & $0.1 \mathrm{MNaOH}$ & $\begin{array}{l}\text { Stable Po, involved with long term transformation of } \\
\mathrm{P} \text { in soils (Unit: } \mathrm{m} \mathrm{P} \mathrm{kg}^{-1} \text { ) }\end{array}$ \\
\hline 10 & Sonic Po & $0.1 \mathrm{M} \mathrm{NaOH}$ and sonicate & $\begin{array}{l}\text { Stable Po, involved with long term transformation of } \\
\mathrm{P} \text { in soils (Unit: } \mathrm{mg} \mathrm{P} \mathrm{kg}^{-1} \text { ) }\end{array}$ \\
\hline 11 & Total P & Sum of field $2-10$ & Unit: $\mathrm{mg} \mathrm{P} \mathrm{kg}^{-1}$ \\
\hline 12 & $\mathrm{pH}$ & & Soil pH \\
\hline 13 & Organic C & & Organic carbon content of soil (unit: \%) \\
\hline 14 & Total N(\%) & & Total nitrogen in soil (unit: \%) \\
\hline 15 & Latitude & & Latitude, decimal; positive $=$ north, negative $=$ south \\
\hline 16 & Longitude & & Longitude, decimal ; positive $=$ east, negative $=$ west \\
\hline 17 & Reference & & Author name and publication year \\
\hline
\end{tabular}

* Pi stands for inorganic $\mathrm{P}$ and $\mathrm{Po}$ is for organic $\mathrm{P}$ in Table 1.

measurements of $\mathrm{P}$ fractions to add to the 88 values from soils in natural ecosystems that Cross and Schlesinger (1995) compiled. The complete Hedley P database and references for data are included in the Supplement.

The primary data file includes 17 fields (Table 1). In addition to the Hedley P fraction variables used in Cross and Schlesinger (1995), we also compiled information on soil $\mathrm{pH}$, organic carbon and nitrogen content of soil, as well as the geographic location of the measurement site(longitude and latitude). In some cases, the referenced studies did not report the longitude and latitude of the measurement; we derived the approximate longitude and latitude information by geocoding the name of the location in Google maps (http://maps.google.com). The spatial distribution of the collected data is shown in Fig. 1.

\subsection{Data analysis}

In this study, Hedley P fractions were grouped into five soil P fractions (Table 2) based on previous studies (Cross and Schlesinger, 1995; Hedley and Stewart, 1982; Smeck, 1985; Tiessen and Cole, 1984). Furthermore, labile P in soil is defined as the sum of resin $\mathrm{Pi}$, bicarbonate $\mathrm{Pi}$ and bicarbonate Po (Cross and Schlesinger, 1995; Johnson et al., 2003; Tiessen and Moir, 1993).

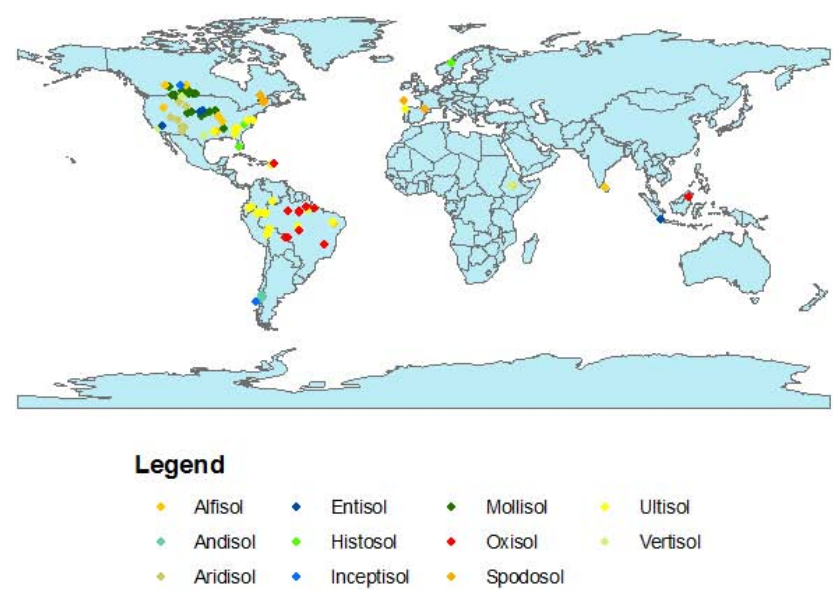

Fig. 1. Distribution of data locations. Some locations contain multiple data entries.

The data were ordered following Cross and Schlesinger (1995), which was based on the weathering sequence of soil orders defined by Smeck (1985). Andisol, Histosol, Entisol, and Inceptisol orders are slightly weathered soils. Aridsol, Vertisol, Mollisol, and Alfisol comprise intermediately weathered soils. Spodosol, Ultisol, and Oxisol represent strongly weathered soils. Compared with Cross and Schlesinger (1995), we have two additional special soil 
Table 2. Terminology of phosphorus forms used in this study and their correspondence to the defined $\mathrm{P}$ fractions using Hedley method.

\begin{tabular}{|c|c|c|}
\hline & This study & Hedley Method \\
\hline 1 & Labile Pi & $\begin{array}{l}\text { Resin Pi } \\
\text { Bicarbonate Pi }\end{array}$ \\
\hline 2 & Secondary mineral Pi & $\begin{array}{l}\text { Hydroxide Pi } \\
\text { Sonic Pi }\end{array}$ \\
\hline 3 & Primary mineral $\mathrm{P}$ & Apatite $\mathrm{P}$ \\
\hline 4 & Occluded P & Residue P \\
\hline 5 & Organic P & $\begin{array}{l}\text { Bicarbonate Po } \\
\text { Hydroxide Po } \\
\text { Sonic Po }\end{array}$ \\
\hline 6 & Labile P (Available P) & $\begin{array}{l}\text { Resin Pi } \\
\text { Bicarbonate Pi } \\
\text { Bicarbonate Po }\end{array}$ \\
\hline 7 & Soluble P & Resin Pi \\
\hline 8 & Non-occluded P & $\begin{array}{l}\text { Bicarbonate Pi } \\
\text { Hydroxide Pi } \\
\text { Sonic Pi }\end{array}$ \\
\hline
\end{tabular}

orders, i.e. Andisols and Histosols. All data were analyzed using the R statistical agricolae package (De Mendiburu, 2009). One-way ANOVA was conducted to analyze total soil $\mathrm{P}$, labile $\mathrm{P}$, and percentage of labile $\mathrm{P}$ as bicarbonate-Po to test whether or not their means in each soil order are all equal. A posteriori differences between the means for different soil orders were then calculated with the Least Significance Difference (LSD) test.

\section{Results}

\subsection{Total Soil P}

Total P generally decreases with increasingly weathered soil orders, but also depends on $\mathrm{P}$ concentration of soil parent material (Fig. 2). Mean total P is highest ( $903 \mathrm{mg} \mathrm{P} / \mathrm{kg}$ soil) in Andisols, which are slightly weathered soils derived from volcanic ash with high $\mathrm{P}$ content. Mean total P in Histosols is also high (628 mg P/kg soil), mainly because Histosols contain a large amount of partially decomposed organic matter that has accumulated a large amount of P (Schlichting et al., 2002). Total $P$ in slightly weathered soils such as Entisols (580 $\mathrm{mg} \mathrm{Pg}^{-1}$ ) and Inceptisols (492 $\mathrm{mg} \mathrm{P} \mathrm{kg}^{-1}$ ) is significantly higher than that of highly weathered Spodosols (293 $\mathrm{mg} \mathrm{Pg}^{-1}$ ), Ultisols (225 $\left.\mathrm{mg} \mathrm{P} \mathrm{kg}^{-1}\right)$, and Oxisols $\left(193 \mathrm{mg} \mathrm{P} \mathrm{kg}^{-1}\right)$. The relatively high total $\mathrm{P}$ in Mol-

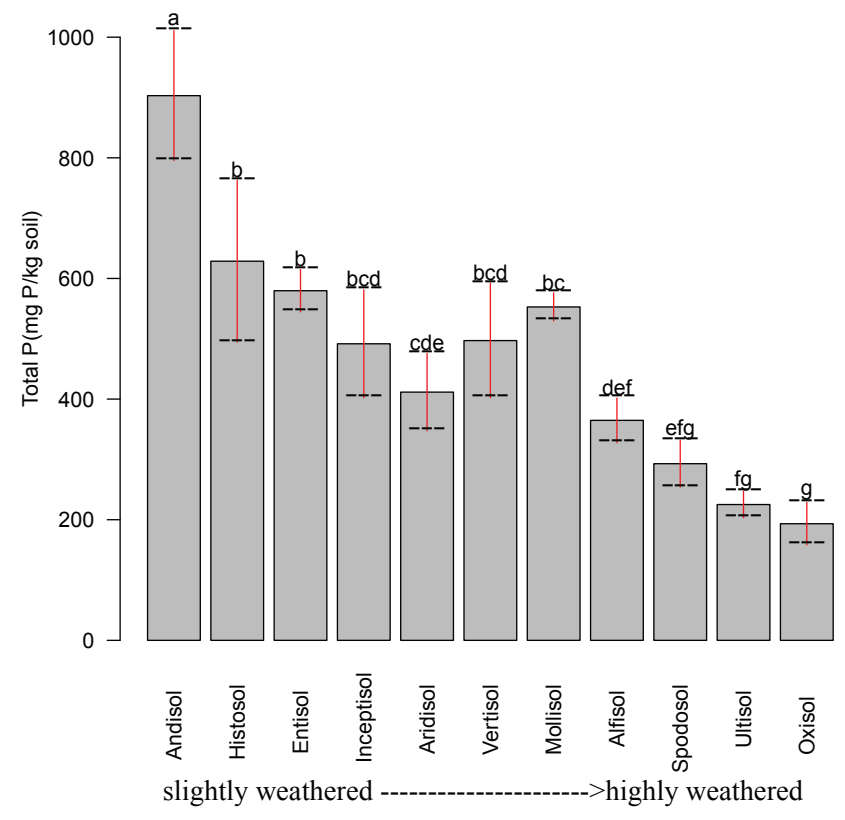

Fig. 2. Mean total soil $P$ in each soil order with one standard error. Different letters indicate significant differences of total soil $\mathrm{P}$ among soil orders at $p<0.05$. Slightly weathered soils: Andisols, Histosols, Entisols, Inceptisols; Intermediately weathered soils: Aridisols, Vertisols, Mollisols, Alfisols; Highly weathered soils: Ultisols, Spodosol, Oxisols.

lisols $\left(553 \mathrm{mg} \mathrm{P} \mathrm{kg}^{-1}\right.$ ) may be attributed to $\mathrm{P}$ abundant loess derived parent material.

\subsection{Soil P fractions}

Since differences in the absolute value of soil $\mathrm{P}$ depend on both weathering stages and parent material, fractions of different soil $\mathrm{P}$ forms relative to total $\mathrm{P}$ were used to evaluate the relationship between distribution of $\mathrm{P}$ forms and soil orders (Fig. 3). Labile Pi, which is considered readily available for plants, constitutes a small fraction of total soil $\mathrm{P}$ for all soil orders. The variation of the labile Pi fraction is relatively small (5 to $10 \%$ ) across all soil development stages. Even the highly weathered Oxisols have $5 \%$ of total $\mathrm{P}$ as labile $\mathrm{Pi}$, which is comparable with intermediately-weathered soils, probably indicating the biological control on labile $\mathrm{Pi}$ in highly weathered soils. Secondary mineral $\mathrm{Pi}$, which is extracted with $\mathrm{NaOH}$ in Hedley method and defined as inorganic $\mathrm{P}$ adsorbed to the surface of secondary $\mathrm{Fe}$ and $\mathrm{Al}$ minerals, also constitutes a relative small fraction of total $P$ across all soil orders (4\% to $17 \%$ ). The fraction of total $\mathrm{P}$ in secondary mineral form, however, increases with the stage of weathering. In highly weathered soils such as Ultisols and Oxisols, where soils are acidic and $\mathrm{Al}$ and $\mathrm{Fe}$ oxides dominate soil minerals, most soil $\mathrm{P}$ is bound to secondary minerals leading to higher fraction of secondary mineral Pi. The sum of labile Pi and secondary mineral Pi (non-occluded 
$\mathrm{P}$ in Walker and Syers' conceptual model) constitutes about $20 \%$ of total P even in highly weathered Ultisols and Oxisols, a larger amount than in Walker and Syers (1976). Apatite $P$ decreases with soil weathering. Lightly weathered Entisols have a high percentage of $\mathrm{P}$ in apatite (47\%), while in strongly weathered Oxisols, apatite P only accounts for about $3 \%$ of total soil P. Apatite P makes up $64 \%$ of total soil $\mathrm{P}$ in Aridsols, the highest among all soil orders. This reflects both the moderate weathering stage of Aridsols due to dry climate condition and the generation of secondary calcium phosphate in Aridsols, where the high concentrations of calcium carbonate leads to the chemical reaction between released $\mathrm{P}$ from primary apatite $\mathrm{P}$ and calcium minerals under neutral or alkaline conditions (Cross and Schlesinger, 1995; Lajtha and Schlesinger, 1988). In contrast to apatite $\mathrm{P}$, occluded $\mathrm{P}$ increases with the weathering stage of soils. Occluded P makes up about $20 \%$ of total soil P in slightly weathered Entisols, Inceptisols, and Aridsols, while it constitutes $50 \%$ and $59 \%$ of total soil P in highly weathered Ultisols and Oxisols. The exceptions to the general patterns here are Andisols and Histosols, the two special soil orders in USDA soil taxonomy. Although they are slightly weathered soils, Histosols have a large fraction of organic $\mathrm{P}$ and low fraction of apatite $\mathrm{P}$ because Histosols, unlike other soils, are characterized by large surface accumulations of slowly decomposing organic matter. The high fraction of occluded $\mathrm{P}$ in Histosols is associated with highly stable organic materials such as lignin and organometallic complexes (Schlichting et al., 2002). Andisols have andic properties - unique chemical and physical properties such as rapid accumulation of organic matter and high P retention due to high levels of Ferrihydrite, Imogolite, and Allophane. Therefore Andisols has large fractions of $\mathrm{P}$ in organic, secondary, occluded form and low fractions of apatite $\mathrm{P}$ (Satti et al., 2007).

\subsubsection{Soil $P$ availability and $P$ demand}

Labile P, defined as the part of soil P that moves most readily among plants, soil biota, soil solution, and loosely bound inorganic pools and easily mineralized organic pools, is considered to be the sum of resin $\mathrm{Pi}$, bicarbonate $\mathrm{Pi}$ and bicarbonate Po in Hedley fractionation method (Sect. 2.2). The mean labile $\mathrm{P}$ ranges from around $100 \mathrm{mg} \mathrm{kg}^{-1}$ in slightly weathered soils to about $20 \mathrm{mg} \mathrm{P} \mathrm{kg}^{-1}$ in highly weathered soils, decreasing with the weathering stages of the soils (Fig. 4a). The importance of bicarbonate Po to soil labile $\mathrm{P}$ increases as soil development proceeds (Fig. 4b), as parent material $\mathrm{P}$ diminishes and organic and occluded forms of soil $\mathrm{P}$ increasingly dominate. Two special soil orders, Andisols and Histosols, have a high percentage of labile $\mathrm{P}$ as bicarbonate Po. The high value in Andisols reflects the rapid soil particle formation from easily weathered volcanic ash (Satti et al., 2007), while the dominance of bicarbonate Po in Histosol labile $\mathrm{P}$ is mainly from $\mathrm{P}$ in accumulating organic matter.

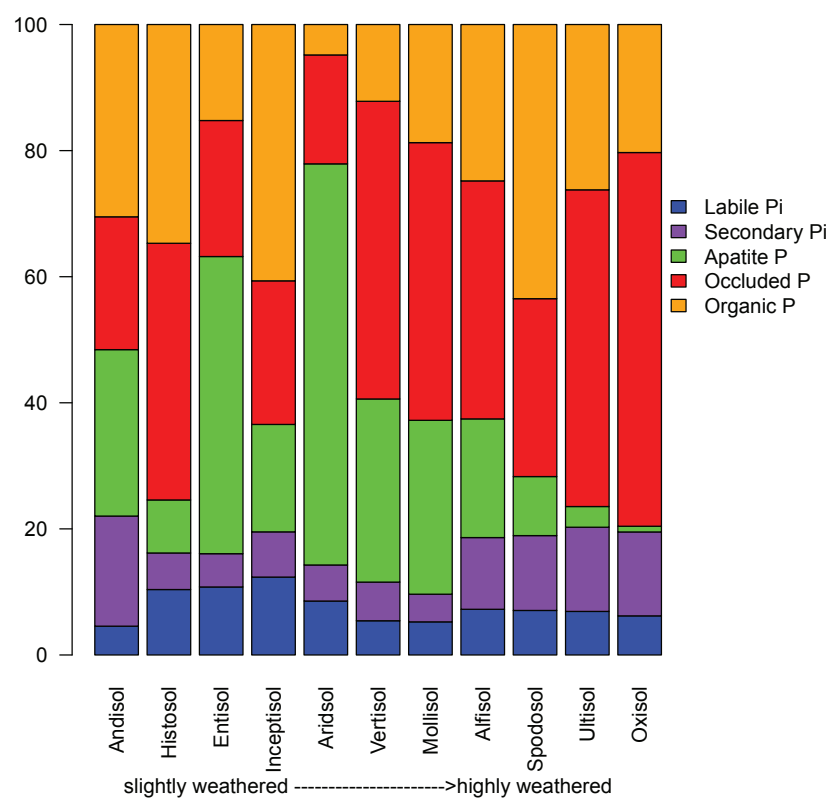

Fig. 3. Fractions of different soil $\mathrm{P}$ expressed as a percentage of total soil P. Slightly weathered soils: Andisols, Histosols, Entisols, Inceptisols; Intermediately weathered soils: Aridisols, Vertisols, Mollisols, Alfisols; Highly weathered soils: Ultisols, Spodosol, Oxisols.

Table 3. Annual litterfall P flux in tropical, temperate forests.

\begin{tabular}{|c|c|c|}
\hline & \multicolumn{2}{|l|}{ Litterfall P } \\
\hline & $\begin{array}{l}\text { Mean } \pm \text { sd } \\
\left(\mathrm{kg} \mathrm{Pha}^{-1} \mathrm{yr}^{-1}\right)\end{array}$ & $n$ \\
\hline Tropical forests & $5.81 \pm 4.49$ & 36 \\
\hline Temperate forests & $3.86 \pm 4.73$ & 122 \\
\hline
\end{tabular}

Labile $\mathrm{P}$ is considered available to plants in the short term or over the course of a growing season (Cross and Schlesinger, 1995; Johnson et al., 2003; Tiessen and Moir, 1993). We investigated whether this labile $P$ can satisfy the $P$ requirement of forest ecosystems. We summarized mean litterfall $\mathrm{P}$ for tropical and temperate forests based on a litterfall database (Holland et al., unpublished) as shown in Table 3. Total $\mathrm{P}$ requirement is defined as litterfall $\mathrm{P}$ plus $\mathrm{P}$ in wood increment and $\mathrm{P}$ required for root growth. Unfortunately there are few data on $\mathrm{P}$ in wood increment and root growth. Campo et al. (2001) suggested that $P$ required for root growth is comparable to aboveground litterfall $\mathrm{P}$ in secondary seasonally dry tropical forests. The data in Johnson and Lindberg (1992) suggested that root requirement of $P$ in temperate forests is about half of the aboveground requirement. It was also suggested that $\mathrm{P}$ in annual wood increment in temperate forests is about one third of annual litterfall P (Johnson and Lindberg, 1992) . Following Johnson et al. (2003), we estimated Hedley-labile P per kg ha ${ }^{-1}$ (Table 4) in order to 

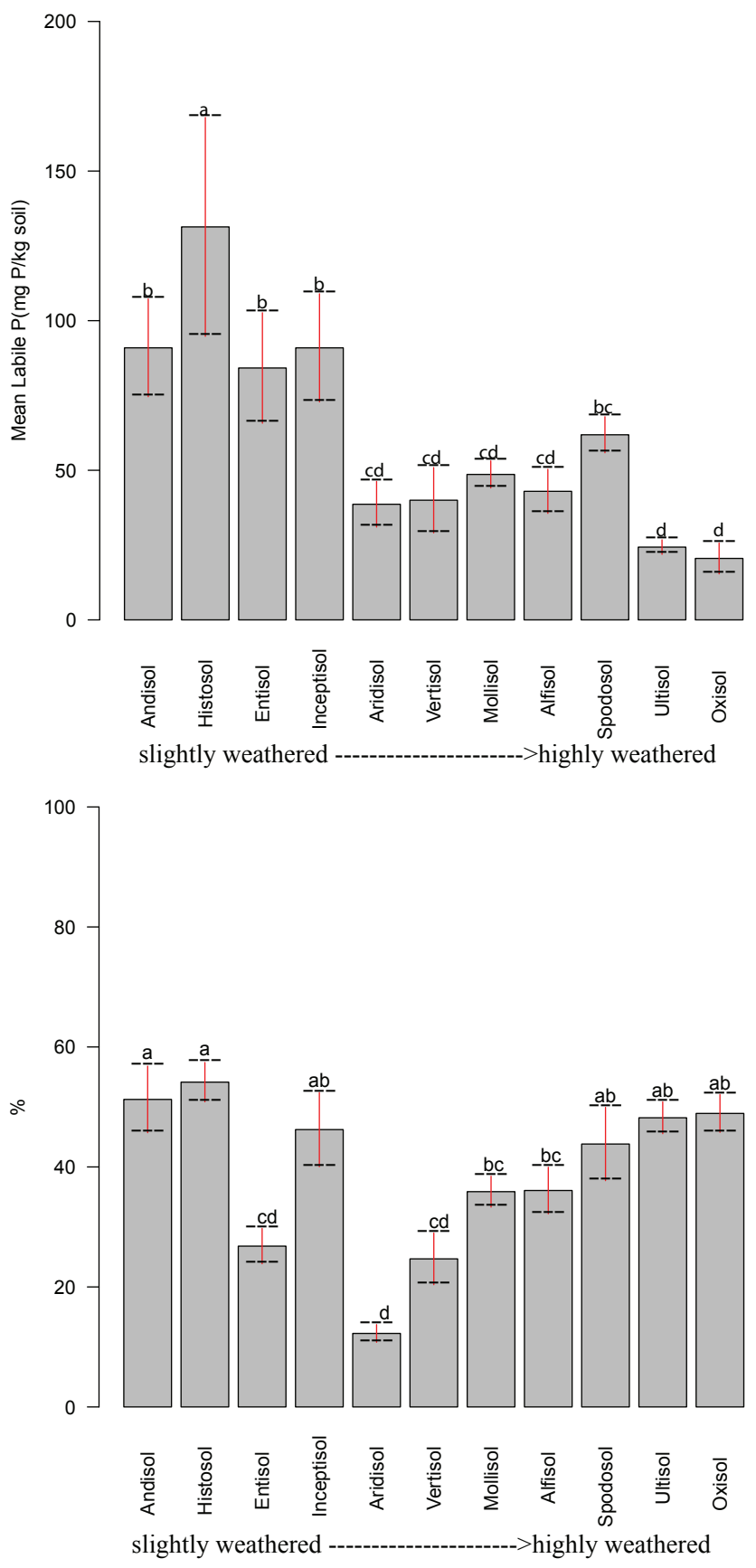

Fig. 4. (a) Mean labile $\mathrm{P}$ (Unit: $\mathrm{mg} \mathrm{P} \mathrm{kg}^{-1}$ soil) in different soil orders; (b) bicarbonate Po as a percentage of labile $\mathrm{P}$ in different soil orders(unit: percentage). Slightly weathered soils: Andisols, Histosols, Entisols, Inceptisols; Intermediately weathered soils: Aridisols, Vertisols, Mollisols, Alfisols; Highly weathered soils: Ultisols, Spodosol, Oxisols.

compare with estimated vegetation $\mathrm{P}$ requirement (Table 3). We assumed the bulk density of forest soils A horizons to be $0.64 \mathrm{~g} \mathrm{~cm}^{-3}$ as in Johnson et al. (2003).
Table 4. Mean (SD) for Hedley-labile P in A-horizons (assumed up to $15 \mathrm{~cm}$ depth) of soils that typically support forests.

\begin{tabular}{llll}
\hline & $n$ & $\begin{array}{l}\text { Labile } \mathrm{P} \\
\text { concentration } \\
\mathrm{mg} \mathrm{P} \mathrm{kg}^{-1}\end{array}$ & $\begin{array}{l}\text { Labile P } \\
\text { amount } \\
\mathrm{Kg} \mathrm{ha}^{-1}\end{array}$ \\
\hline Entisols & 9 & $84.19(55.39)$ & 80.82 \\
Inceptisols & 9 & $90.92(54.21)$ & 87.28 \\
Alfisols & 17 & $42.97(30.40)$ & 41.25 \\
Spodosols & 11 & $61.86(19.98)$ & 59.39 \\
Ultisols & 38 & $24.32(14.98)$ & 23.34 \\
Oxisols & 14 & $20.54(19.35)$ & 19.72 \\
\hline
\end{tabular}

The size of the labile P pool (Table 4) is far greater than annual litterfall $\mathrm{P}$ (Table 3 ) in all cases, and greater than P requirement even if we estimate annual $P$ requirement is three times litterfall $\mathrm{P}$ in order to more than accommodate root and stem required $\mathrm{P}$ uptake.

\subsection{The relationships between soil $\mathrm{C}, \mathrm{N}$ and $\mathrm{Po}$}

$\mathrm{C}$ and $\mathrm{N}$ are highly correlated in all soils with $r^{2}$-value of 0.89 (figure not shown here), indicating the close coupling of $\mathrm{C}$ and $\mathrm{N}$ in soils. The close association of $\mathrm{C}$ and $\mathrm{N}$ in soils can be attributed to the fact that terrestrial plants have relatively constrained $\mathrm{C}: \mathrm{N}$ ratios and plant litter is the primary source of soil C and N (Cleveland and Liptzin, 2007). However, both $\mathrm{C}$ and $\mathrm{N}$ were poorly correlated with organic $\mathrm{P}$ in soils ( $\mathrm{cr}=0.28$ and 0.26, respectively). As shown in Fig. 5, N:Po ratios range from less than 10 to around 200 across all soil orders. For slightly weathered soils (Andisols, Histosols, Entisols, Inceptisols) and intermediately weathered soils (Aridsols, Mollisols, Vertisols, and Alfisols), N:Po ratios are relatively constrained, ranging between 0 to 50 with mean values of 21.26 and 22.08 respectively. For highly weathered soils (Spodosols, Ultisols, and Oxisols), the variability in N:Po ratios is much larger, with a mean value of 40.34 . It seems that as soils develop to highly weathered stages, when most of soil $\mathrm{P}$ has been depleted, organic $\mathrm{P}$ becomes decoupled from soil organic $\mathrm{C}$ and $\mathrm{N}$.

\section{Discussions}

\subsection{P transformations during pedogenesis}

Our expansion of the Cross and Schlesinger (1995) Hedley P database generally support the Walker and Syers (1976) conceptual model: the gradual decrease and eventual depletion of primary mineral $\mathrm{P}$ (mainly apatite $\mathrm{P}$ ); the continual increase and eventual dominance of occluded $\mathrm{P}$; and the overall decrease of total $\mathrm{P}$ during soil development. The fraction of organic $\mathrm{P}$ in total soil $\mathrm{P}$ first increases and then decreases 

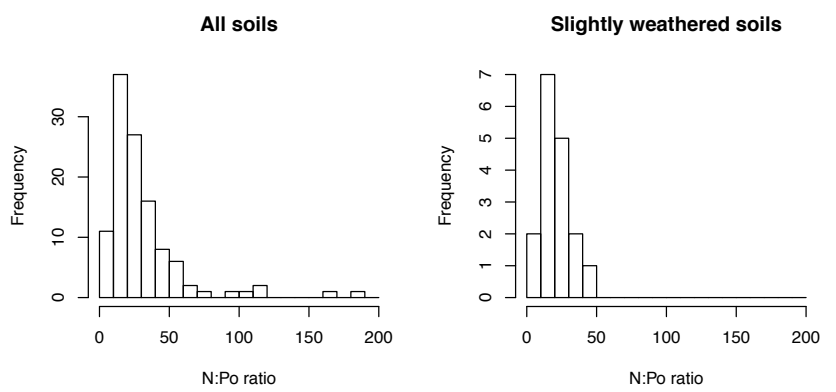

Intermediately weathered soils
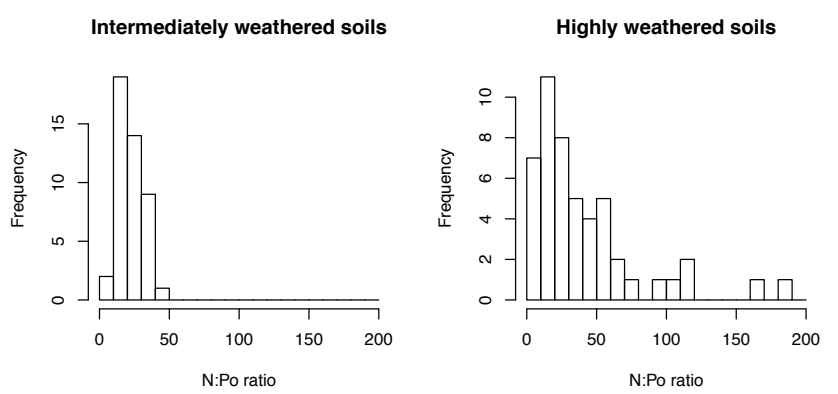

Fig. 5. Histograms of N:Po ratios in soils of all weathering stages, slightly weathered soils(Andisols, Histosols, Entisols, and Inceptisols), intermediately weathered soils(Aridsols, Vertisols, Mollisols, and Alfisols) and highly weathered soils(Spodosols, Ultisols, and Oxisols).

with the degree of the weathering. As soil develops, organic matter accumulates leading to an increase of the organic $\mathrm{P}$ fraction. With the progression of weathering and the increase of $\mathrm{Al}$ and $\mathrm{Fe}$ oxide minerals and the decrease of soil $\mathrm{pH}$, $\mathrm{P}$ mineralized from organic matter adsorbs to the surface of minerals and may further become encapsulated inside of $\mathrm{Fe}$ an Al minerals, becoming occluded P. This is consistent with previous studies that show occluded $\mathrm{P}$ increases at the expense of organic P in highly weathered soils (Crews et al., 1995).

The database analysis however contrasts with the Walker and Syers (1976) model in that we found labile Pi and secondary mineral Pi(non-occluded P in Walker and Syers' model) to be a significant fraction of total $\mathrm{P}$ throughout all soil orders with different weathering stages. Crews et al. (1995) tested the Walker and Syers (1976) conceptual model by analyzing changes in soil $\mathrm{P}$ on a soil chronosequence with six sites ranging from 300 years to 4 million years old. They also found the persistence of a non-occluded $\mathrm{P}$ pool throughout their choronosequence. They proposed two possible causes: the accumulation effect of Asian dust deposition in the older sites and the possible dissolution of occluded $\mathrm{P}$ due to mycorrhizal interaction. Studies have shown that $\mathrm{P}$ can be transferred via dust over extreme long distances and provide important inputs of $\mathrm{P}$ for terrestrial ecosystems (Neff et al., 2006; Okin et al., 2004; Swap et al., 1992), especially in highly weathered tropical soils (Ma- howald et al., 2005; Okin et al., 2004; Swap et al., 1992). There is also evidence that the occlusion of $\mathrm{P}$ by secondary $\mathrm{Fe}$ and $\mathrm{Al}$ minerals is not entirely permanent. Plants can establish a symbiotic association with certain types of mycorrhizal fungi, which have the capacity to dissolve certain Poccluding minerals (Crews et al., 1995; Tiessen et al., 1994). Cluster roots produced by some plants function in severely P-limited landscapes, "mining" P from strongly adsorbed forms (Lambers et al., 2008). P bound in Fe minerals can also be released under anaerobic conditions in wet tropical forests (Chacon et al., 2006; Liptzin and Silver, 2009). In addition, several studies indicate that the depletion of nonoccluded $\mathrm{P}$ in older soils is restricted to stable tectonic settings and is unlikely to occur when there is even moderate uplift and erosion (Porder et al., 2007). Although all these processes may prevent the highly weathered soil orders from entering the "terminal state" predicted by Walker and Syers' model, it seems unlikely these soils can rejuvenate its $\mathrm{P}$ supply considering the fact that (1) parent material $\mathrm{P}$ is depleted and most of total $\mathrm{P}$ has been lost through leaching during soil development; (2) these soils usually have enormous $\mathrm{P}$ sorption capacities because of their high $\mathrm{Al}$ and Fe minerals content (McGroddy et al., 2008) although there is some evidence that Fe-bound $\mathrm{P}$ can be released under wet conditions due to Fe reduction; and (3) the rate of external input from dust and uplift is usually very small (Williams et al., 1997). Instead these soils may maintain a relatively constant soil $\mathrm{P}$ availability at a lower level of non-occluded soil P.

\subsection{Labile $P$ vs. vegetation $P$ demand}

By analyzing the labile $\mathrm{P}$ and vegetation $\mathrm{P}$ demand, we found that labile $\mathrm{P}$ is generally much higher than vegetation demand, even in highly weathered soils commonly considered $\mathrm{P}$ limited. This is consistent with earlier findings that soil labile $\mathrm{P}$ based on Hedley fractionation method is far greater than the vegetation P requirement (Araújo et al., 2004; Johnson et al., 2003; Thomas et al., 1999; Valdespino et al., 2009). In particular, Johnson et al. (2003) compared soil labile $\mathrm{P}$ in forest soils and estimated annual forest $\mathrm{P}$ demand and found that labile $\mathrm{P}$ pools in soils were several times higher than annual $\mathrm{P}$ demand in humid tropical forests, even though many tropical forests are considered $\mathrm{P}$ limited. The paradox can be explained if we account for microbial demand of $\mathrm{P}$, which could be fairly large considering the high C:P ratio of litter (McGroddy et al., 2004) and soil organic matter and relatively low $\mathrm{C}: \mathrm{P}$ ratio of microbial biomass (Cleveland and Liptzin, 2007; Cole et al., 1977). Cole et al. (1977) showed that the P uptake by microbial and other decomposers is the largest annual P flux in their $\mathrm{P}$ budget. In the $\mathrm{P}$ budget of two grassland sites given by Cole et al. (1977), root uptake of $\mathrm{P}$ vs. microbial uptake of $\mathrm{P}$ was $5.26 \mathrm{~kg} \mathrm{Pha}^{-1} \mathrm{yr}^{-1}$ vs. $24.57 \mathrm{~kg} \mathrm{Pha}^{-1} \mathrm{yr}^{-1}$ and $12.00 \mathrm{~kg} \mathrm{Pha}^{-1} \mathrm{yr}^{-1}$ vs. $31.60 \mathrm{kgPha}^{-1} \mathrm{yr}^{-1}$ respectively. Unfortunately there are few measurements on the magnitude 
of the microbial immobilization fluxes of P. Studies on microbial growth have shown that the proportion of total $\mathrm{P}$ immobilized by microorganisms $(8.8 \%)$ in the surface soil is higher than that of $\mathrm{N}(4.7 \%)$ and the microbial fraction of total P pool is almost ten times higher than estimated available P (Aponte et al., 2010). During the growing season, the microbes immobilized the major part of the mineralized $\mathrm{P}$, which resulted in low net mineralization (Schmidt et al., 1999). The mineralized $P$ can be quickly immobilized by microorganisms and made unavailable for plants to use. Furthermore, studies also suggest that microbial processes in tropical regions may be limited by soil $\mathrm{P}$ availability. Cleveland and Townsend (2006) showed P fertilization resulted in an increase of soil respiration by almost $40 \%$ in a tropical forest experiment. In a litterfall fertilization experiment in a wet tropical forest in Costa Rica, the increase of litterfall and total $\mathrm{P}$ inputs led to an average $22 \%$ increase in leaf litter production 2-6 months following litter addition, suggesting a strong link between total $\mathrm{P}$ input and forest productivity and highly efficient cycling of leaf litter P in P-limited tropical forests. However, the two low P-fertility sites in this experiment demonstrated a net negative response to litter addition, because the large inputs of litter and low soil P led to the net immobilization of P by microbes (Wood et al., 2009). All of this suggests that $\mathrm{P}$ availability of plants might be strongly controlled by microbial dynamics. Although high microbial immobilization could accentuate $\mathrm{P}$ limitation on plant growth, microbial immobilization could act to prevent $\mathrm{P}$ from being adsorbed onto or occluded into secondary minerals or leaching out of the system, therefore represent an important biological reservoir of $\mathrm{P}$ in soils.

Since both plants and microbes compete for labile $\mathrm{P}$ in soils and immobilization of labile $\mathrm{P}$ is substantial, we should be cautious when we consider labile P, defined as sum of resin- $\mathrm{Pi}$, bicarbonate $\mathrm{Pi}$ and bicarbonte $\mathrm{Po}$, as available $\mathrm{P}$ for plant uptake. Instead we should emphasize that labile $\mathrm{P}$ is available for both root uptake and microbial immobilization.

Questions remain about how to relate the Hedley fractions $P$ with available $P$ for plant growth. Further field experiments are needed to link the operationally defined $\mathrm{P}$ pools to $\mathrm{P}$ fertility in soils for plant productivity. The available Hedley $\mathrm{P}$ database, however, will be useful for constraining soil $\mathrm{P}$ pools in terrestrial biogeochemical models and can help us gain further insight into the processes controlling $\mathrm{P}$ cycling and the role of $\mathrm{P}$ in controlling plant productivity when integrated with modeling studies.

\subsection{C:N:Po stoichiometry in soils}

Our analysis of the database also show that $\mathrm{C}$ and $\mathrm{N}$ in soil organic matter are closely linked in all soil orders, but $\mathrm{P}$ is decoupled from $\mathrm{C}$ and $\mathrm{N}$ in highly weathered soils with larger variations of N:Po ratio and higher mean value of N:Po, compared with slightly and intermediately weathered soils . In tropical forests, leaf litter C:P and N:P ratios are generally higher than that of temperate forests (McGroddy et al., 2004) because of the low $\mathrm{P}$ supply in highly weathered tropical soils and more efficient resorption of $\mathrm{P}$ prior to leaf senescence (McGroddy et al., 2004; Vitousek, 1984). This may contribute to higher N:Po ratio in tropical soils. The higher N:Po ratio in highly weathered soils may also reflect a more complete mineralization of soil organic $\mathrm{P}$, compared with mineralization of $\mathrm{C}$ and $\mathrm{N}$. This is consistent with the conceptual model proposed by McGill and Cole (1981) that in soils C and $\mathrm{N}$ are stabilized together and mineralized through biological mineralization, whereas Po can be mineralized independently through biochemical mineralization when soil labile $\mathrm{P}$ is in low supply. McGill and Cole (1981) demonstrated that this independent mineralization of organic $\mathrm{P}$ occurs through enzymatic hydrolysis of phosphate esters, which is catalyzed by the enzyme phosphohydrolase. Phosphohydrolase is released by plant roots and microorganisms in soils and its production could be induced by low P supply in soils.

The higher N:Po ratio could also be used as another indicator of $\mathrm{P}$ limitation in highly weathered soils, along with higher C:P and N:P ratio in foliage (Koerselman and Meuleman, 1996; McGroddy et al., 2004; Reich and Oleksyn, 2004), litterfall (McGroddy et al., 2004; Vitousek, 1984) and soil microbial mass (Cleveland and Liptzin, 2007), as well as higher $\mathrm{P}$ resorption rate in plants.

\section{Conclusions}

Available P in soils is often in limited supply but determining its magnitude in soil is problematic since it is involved in reactions with soil minerals that can lead to its precipitation in unavailable forms. The Hedley sequential fractionation method has been shown to be a useful tool to examine different forms of soil P. We developed a large database, assembled from 178 published Hedley fractionation studies, more than doubling a previous compilation (Cross and Schlesinger 1995), and extended the results of this earlier analysis by including data from 2 additional special soil orders, Andisols and Histosols, and increasing the number of studies from 1 to 14 for the important order Oxisol, thought to be the most $P$ restrictive. We used the data categorized into soil orders to explore trends related to the degree of weathering according to the sequence of soil orders ranked by Smeck (1985). We found that the overall pattern of soil $\mathrm{P}$ transformations along the soil-weathering continuum agrees with the Walker and Syers (1976) conceptual model of (1) a gradual decrease of primary mineral $\mathrm{P},(2)$ a decrease of total $\mathrm{P}$, and (3) a increase and eventual dominance of occluded $P$.

However, we found that the sum of labile Pi and secondary mineral $\mathrm{Pi}$, remains fairly constant fraction, $20 \%$ of $P$, throughout the sequence of soil orders rather than declining with the degree of weathering. Po does show the expected initial increase followed by a decrease resulting in an overall decline in potentially plant available $\mathrm{P}$ forms with 
weathering. However, because of the relatively constant fraction of the labile $\mathrm{Pi}$ and secondary mineral $\mathrm{Pi}$, it appears that, in general, labile $\mathrm{P}$ (sum of labile Pi and Bicarbonate Po) can meet plant demand for all soil orders. Since P limitation to plants is observed in vegetation on highly weathered soils like Oxisols, it appears that labile $\mathrm{P}$ is not equivalent to available $\mathrm{P}$ for plant growth. Perhaps a large fraction is immobilized by microbial decomposers, or possibly, only Po is actually available for plant growth. This is further supported by the decoupling of N:Po in highly weathered soil orders Spodosols, Ultisols, and Oxisols. Additional measurements and experiments are needed to adequately determine plant available $\mathrm{P}$ in soils.

Different $\mathrm{P}$ extraction methods result in different estimates of available P. Previous studies suggested that in acidic often highly weathered soils labile P based on the Bray method may be more appropriate than the Hedley bicarbonate extraction (Cross and Schlesinger, 1995; Johnson et al., 2003). However, the advantage of Hedley fractionation method is that it provides the estimates of different $\mathrm{P}$ forms that have potential to contribute to available $\mathrm{P}$ over a growing season. Furthermore the increasing application of this method in different soils has made it possible to relate the measurement produced by this method with other soil properties such as weathering stages, soil $\mathrm{pH}$, soil organic carbon, providing us an opportunity for better understanding the controls on available $\mathrm{P}$ in soils.

The expanded global Hedley P database is useful both on its own and in conjunction with other soil and vegetation $\mathrm{P}$ data, allowing us not only to estimate soil $\mathrm{P}$ distribution and better understand $\mathrm{P}$ transformations in different stages of soil weathering, but also investigate the interactions of $P$ with other elements in terrestrial ecosystems. The Hedley $\mathrm{P}$ database provides a quantitative foundation for the incorporation of $\mathrm{P}$ cycling dynamics and $\mathrm{P}$ limitation in terrestrial biogeochemical models by providing direct measurements of soil P forms and amounts in soils for use by these models.

\section{Supplementary material related to this article is available online at: http://www.biogeosciences.net/8/2907/2011/ bg-8-2907-2011-supplement.zip.}

Acknowledgements. This research was sponsored by the U.S. Department of Energy, Office of Science, Biological and Environmental Research (BER) programs and performed at Oak Ridge National Laboratory (ORNL). ORNL is managed by UT-Battelle, LLC, for the U.S. Department of Energy under Contract No. DEAC05-00OR22725.

Edited by: E. Veldkamp

\section{References}

Aponte, C., Maranon, T., and Garcia, L. V.: Microbial C, N and $\mathrm{P}$ in soils of Mediterranean oak forests: influence of season, canopy cover and soil depth, Biogeochemistry, 101, 77-92, doi:10.1007/s10533-010-9418-5, 2010.

Araújo, M., Schaefer, C., and Sampaio, E.: Soil phosphorus fractions from toposequences of semi-arid Latosols and Luvisols in northeastern Brazil, Geoderma, 119, 309-321, doi:10.1016/j.geoderma.2003.07.002, 2004.

Bray, R. and Kurtz, L.: Determination of total, organic, and available forms of phosphorus in soils, Soil Sci., 59, 39, 1945.

Campo, J., Maass, M., Jaramillo, V. J., Martİnez-YrÌzar, A., and Sarukh.n, J.: Phosphorus cycling in a Mexican tropical dry forest ecosystem, Biogeochemistry, 53, 161-179, doi:10.1023/A:1010663516029, 2001.

Chacon, N., Silver, W. L., Dubinsky, E. A., and Cusack, D. F.: Iron reduction and soil phosphorus solubilization in humid tropical forests soils: the roles of labile carbon pools and an electron shuttle compound, Biogeochemistry, 78, 67-84, doi:10.1007/s10533-005-2343-3, 2006.

Cleveland, C. and Liptzin, D.: C:N:P stoichiometry in soil: is there a "Redfield ratio" for the microbial biomass?, Biogeochemistry, 85, 235-252, doi:10.1007/s10533-007-9132-0, 2007.

Cleveland, C. C. and Townsend, A. R.: Nutrient additions to a tropical rain forest drive substantial soil carbon dioxide losses to the atmosphere, P. Natl. A. Sci. USA, 103, 10316, doi:10.1073/pnas.0600989103, 2006.

Cole, C. V., Innis, G. S., and Stewart, J.: Simulation of phosphorus cycling in semiarid grasslands, Ecology, 58, 2-15, doi:10.2307/1935104, 1977.

Condron, L. M. and Newman, S.: Revisiting the fundamentals of phosphorus fractionation of sediments and soils, J. Soils Sedim., 11, 830-840, doi:10.1007/s11368-011-0363-2, 2011.

Crews, T., Kitayama, K., Fownes, J., Riley, R., Herbert, D., Mueller-Dombois, D., and Vitousek, P.: Changes in soil phosphorus fractions and ecosystem dynamics across a long chronosequence in Hawaii, Ecology, 76, 1407-1424, doi:10.2307/1938144, 1995.

Cross, A. and Schlesinger, W.: A literature review and evaluation of the. Hedley fractionation: Applications to the biogeochemical cycle of soil phosphorus in natural ecosystems, Geoderma, 64, 197-214, doi:10.1016/0016-7061(94)00023-4, 1995.

De Mendiburu, F.: Agricolae: Statistical Procedures for Agricultural Research, R package version, 1.0-7, 2009.

Elser, J. J., Fagan, W. F., Denno, R. F., Dobberfuhl, D. R., Folarin, A., Huberty, A., Interlandi, S., Kilham, S. S., McCauley, E., and Schulz, K. L.: Nutritional constraints in terrestrial and freshwater food webs, Nature, 408, 578-580, doi:10.1038/35046058, 2000.

Elser, J. J., Bracken, M. E. S., Cleland, E. E., Gruner, D. S., Harpole, W. S., Hillebrand, H., Ngai, J. T., Seabloom, E. W., Shurin, J. B., and Smith, J. E.: Global analysis of nitrogen and phosphorus limitation of primary producers in freshwater, marine and terrestrial ecosystems, Ecol. Lett., 10, 1135-1142, doi:10.1111/j.14610248.2007.01113.x, 2007.

Hedin, L. O.: Global organization of terrestrial plantnutrient interactions, P. Natl. A. Sci., 101, 10849-10850, doi:10.1073/pnas.0404222101, 2004.

Hedley, M. and Stewart, J.: Method to measure microbial phosphate in soils, Soil Biol. Biochem., 14, 377-385, 1982. 
Johnson, A. H., Frizano, J., and Vann, D. R.: Biogeochemical implications of labile phosphorus in forest soils determined by the Hedley fractionation procedure, Oecologia, 135, 487-499, 2003.

Johnson, D. W. and Lindberg, S. E.: Atmospheric deposition and forest nutrient cycling, A synthesis of the Integrated Forest Study, Springer-Verlag, 1992.

Koerselman, W. and Meuleman, A. F. M.: The vegetation N: P ratio: a new tool to detect the nature of nutrient limitation, J. Appl. Ecol., 1441-1450, 1996.

Lajtha, K. and Schlesinger, W. H.: The biogeochemistry of phosphorus cycling and phosphorus availability along a desert soil chronosequence, Ecology, 69, 24-39, 1988.

Lambers, H., Raven, J. A., Shaver, G. R., and Smith, S. E.: Plant nutrient-acquisition strategies change with soil age, Trends Ecol. Evol., 23, 95-103, 2008.

Liptzin, D. and Silver, W. L.: Effects of carbon additions on iron reduction and phosphorus availability in a humid tropical forest soil, Soil Biol. Biochem., 41, 1696-1702, 2009.

Mahowald, N. M., Baker, A. R., Bergametti, G., Brooks, N., Duce, R. A., Jickells, T. D., Kubilay, N., Prospero, J. M., and Tegen, I.: Atmospheric global dust cycle and iron inputs to the ocean, Global Biogeochem. Cycles, 19, doi:10.1029/2004GB002402, 2005.

McGill, W. and Cole, C.: Comparative aspects of cycling of organic C, N, S and P through soil organic matter, Geoderma, 26, 267286, 1981.

McGroddy, M. E., Daufresne, T., and Hedin, L. O.: Scaling of C: N: $\mathrm{P}$ stoichiometry in forests worldwide: implications of terrestrial Redfield-type ratios, Ecology, 85, 2390-2401, 2004.

McGroddy, M. E., Silver, W. L., de Oliveira, R. C., de Mello, W. Z., and Keller, M.: Retention of phosphorus in highly weathered soils under a lowland Amazonian forest ecosystem, J. Geophys. Res., 113, G04012, doi:10.1029/2008jg000756, 2008.

Neff, J. C., Reynolds, R., Sanford, R. L., Fernandez, D., and Lamothe, P.: Controls of Bedrock Geochemistry on Soil and Plant Nutrients in Southeastern Utah, Ecosystems, 9, 879-893, doi:10.1007/s10021-005-0092-8, 2006.

Negassa, W. and Leinweber, P.: How does the Hedley sequential phosphorus fractionation reflect impacts of land use and management on soil phosphorus: A review, J. Plant Nutr. Soil Sc., 172, 305-325, 2009.

Nelson, W., A. Mehlich, and E. Winters (1953), The development, evaluation, and use of soil tests for phosphorus availability, Soil and fertilizer phosphorus in crop nutrition, 153-188.

Okin, G. S., Mahowald, N., Chadwick, O. A., and Artaxo, P.: Impact of desert dust on the biogeochemistry of phosphorus in terrestrial ecosystems, Global Biogeochem. Cyc., 18, doi:10.1029/2003GB002145, 2004.

Olsen, S.: Estimation of available phosphorus in soils by extraction with sodium bicarbonate, US Dept. of Agriculture, 1954.

Porder, S., Vitousek, P., Chadwick, O., Chamberlain, C., and Hilley, G.: Uplift, erosion, and phosphorus limitation in terrestrial ecosystems, Ecosystems, 10, 159-171, doi:10.1007/S10021006-9011-x, 2007.

Reich, P. B. and Oleksyn, J.: Global patterns of plant leaf $\mathrm{N}$ and $\mathrm{P}$ in relation to temperature and latitude, P. Natl. A. Sci. USA, 101, 11001, doi:10.1073/pnas.0403588101, 2004.
Satti, P., Mazzarino, M., Roselli, L., and Crego, P.: Factors affecting soil $\mathrm{P}$ dynamics in temperate volcanic soils of southern Argentina, Geoderma, 139, 229-240, doi:10.1016/j.geoderma.2007.02.005, 2007.

Schlichting, A., Leinweber, P., Meissner, R., and Altermann, M.: Sequentially extracted phosphorus fractions in peat derived soils, J. Nutr. Soil Sci., 165, 290-298, 2002.

Schmidt, I. K., Jonasson, S., and Michelsen, A.: Mineralization and microbial immobilization of $\mathrm{N}$ and $\mathrm{P}$ in arctic soils in relation to season, temperature and nutrient amendment, Appl. Soil Ecol., 11, 147-160, 1999.

Smeck, N.: Phosphorus dynamics in soils and landscapes, Geoderma, 36, 185-199, 1985.

Sterner, R. W. and J. J. Elser: Ecological stoichiometry, Princeton UP, 2002.

Swap, R., Garstang, M., Greco, S., Talbot, R., and KÂllberg, P.: Saharan dust in the Amazon Basin, Tellus B, 44, 133-149, 1992. Thomas, S. M., Johnson, A. H., Frizano, J., Vann, D. R., Zarin, D. J., and Joshi, A.: Phosphorus fractions in montane forest soils of the Cordillera de PiuchuÈ, Chile: biogeochemical implications, Plant Soil, 211, 139-148, 1999.

Tian, H., Chen, G., Zhang, C., Melillo, J. M., and Hall, C. A. S.: Pattern and variation of $\mathrm{C}: \mathrm{N}: \mathrm{P}$ ratios in China's soils: a synthesis of observational data, Biogeochemistry, 98, 139-151, doi:10.1007/s10533-009-9382-0, 2010.

Tiessen, H. and Cole, J.: Pathways of Phosphorus Transformations in Soils of Differing Pedogenesis1, Soil Sci. Soc. Am. J., 48, 853, 1984.

Tiessen, H. and Moir, J. O.: Characterization of available P by sequential extraction, in Soil sampling and methods of analysis, edited by: Carter, M. and Gregorich, E.: CRC Press, Taylor \& Francis Group, Boca Raton, FL, 75-86, 1993.

Tiessen, H., Chacon, P., and Cuevas, E.: Phosphorus and nitrogen status in soils and vegetation along a toposequence of dystrophic rainforests on the upper Rio Negro, Oecologia, 99, 145-150, 1994.

Valdespino, P., Romualdo, R., Cadenazzi, L., and Campo, J.: Phosphorus cycling in primary and secondary seasonally dry tropical forests in Mexico, Ann. Forest Sci., 66, 107-107, 2009.

Vitousek, P.: Litterfall, nutrient cycling, and nutrient limitation in tropical forests, Ecology, 65, 285-298, 1984.

Vitousek, P. and Howarth, R.: Nitrogen limitation on land and in the sea: how can it occur?, Biogeochemistry, 13, 87-115, 1991.

Walker, T. and Syers, J.: The fate of phosphorus during pedogenesis, Geoderma, 15, 1-19, 1976.

Wardle, D., Walker, L., and Bardgett, R.: Ecosystem properties and forest decline in contrasting long-term chronosequences, Science, 305, 509, 2004.

Williams, M. R., Fisher, T. R., and Melack, J. M.: Chemical composition and deposition of rain in the central Amazon, Brazil, Atmos. Environ., 31, 207-217, 1997.

Wood, T. E., Lawrence, D., Clark, D. A., and Chazdon, R. L.: Rain forest nutrient cycling and productivity in response to large-scale litter manipulation, Ecology, 90, 109-121, 2009. 